\title{
Implementasi Konsep Belajar Humanistik pada Siswa dengan Tahap Operasional Formal di SMK Miftahul Khair
}

\author{
Nailil Maslukiyah, Prasetio Rumondor \\ Program Studi Interdisciplinary Islamic Studies, Program Pascasarjana \\ Universitas Islam Negeri Sunan Kalijaga, Yogyakarta
}

\begin{abstract}
Abstrak. Konsep belajar yang diusung humanistik adalah memanusiakan manusia, dan lebih menekankan proses daripada hasil belajar. Penelitian ini dilakukan untuk mengetahui pengimplementasian konsep belajar humanistik bagi siswa tahap operasional formal di SMK Miftahul Khair yang berada di bawah naungan pesantren. Penelitian ini menggunakan pendekatan kualitatif deskriptif. Pengumpulan data dalam penelitian ini menggunakan wawancara semi terstruktur dan observasi. Hal itu dilakukan untuk mengetahui validitas dan konsistensi data yang diperoleh. Adapun hasil dari penelitian ini adalah terdapat beberapa strategi yang digunakan guru dalam mengimplementasikan pembelajaran humanistik pada siswa, yaitu: (1) Memberikan respon positif terhadap siswa baik verbal maupun nonverbal, seperti menghargai siswa, memberikan apresiasi (misal pujian), berlaku adil, tersenyum, dan lain-lain; (2) Memberikan cerita inspiratif untuk menumbuhkan serta meningkatkan hasrat dan minat belajar siswa, di mana hal tersebut berdampak terhadap perubahan siswa (meliputi pengetahuan, sifat, dan perilaku siswa); (3) Pemilihan metode belajar yang tepat dan menyenangkan agar proses pembelajaran menjadi bermakna bagi siswa; dan (4) Membuat siswa merasa nyaman dengan tidak memberikan ancaman atau kecaman terhadap siswa, sehingga siswa merasa bebas berekspresi dalam pembelajaran.
\end{abstract}

Kata Kunci: belajar humanistik, sekolah menengah kejuruan, tahap operasional formal

\section{The Implementation of Humanistic Learning Concept on Students with Formal Operational Stage at Miftahul Khair Vocational School}

Abstract. The concept of learning which so called humanistic was humanizing human beings and emphasizes the process rather than learning outcomes. This research was conducted to determine the implementation of the concept of humanist learning for students in the formal operational stage at the Miftahul Khair's Vocational High School under the auspices of the Pesantren. The study used a descriptive qualitative approach. The data collection, however, used semi-structured interviews and observations. it was done to determine the validity and consistency of the data obtained. The results stated that there were several strategies used by teachers in implementing humanistic learning in students, namely: (1) Giving positive responses to students both verbally and non-verbally such as respecting students, giving appreciation (ex: praise), acting fairly, smiling, etc.; (2) Provide inspirational stories to foster and increase the desires and interest in student learning, where it has an impact on student change (including knowledge, nature, and behavior of students); (3) The selection of appropriate and fun learning methods so that the learning process becomes meaningful for students; and (4) Make students feel comfortable by not giving threats or criticism to students, so students feel free to express themselves in learning.

Keywords: formal operational stages, humanistic learning, vocational high school

Korespondensi: Nailil Maslukiyah. Email: naililmaslukiyah@gmail.com 
Belajar merupakan kegiatan vital dalam setiap usaha pendidikan, yang melibatkan aktivitas psikis dan mental dalam prosesnya. Robert Gagne memberikan dua definisi belajar, yaitu belajar adalah suatu proses untuk memperoleh motivasi dalam pengetahuan, keterampilan, kebiasaan, dan tingkah laku. Selain itu, ia mengatakan bahwa belajar adalah penguasaan pengetahuan atau keterampilan yang diperoleh dari instruksi (Lahir et al, 2017). Selanjutnya, Gagne berpendapat bahwa hasil belajar siswa terbagi menjadi lima kategori: (a) informasi verbal, (b) keterampilan intelektual, (c) keterampilan motorik, (d) sikap, dan (e) strategi kognitif (Nurhasanah \& Sobandi, 2016). Adapun hasil rangkaian proses belajar tersebut dilakukan dalam bentuk keterlibatannya baik dalam pendidikan informal, formal dan/atau pendidikan nonformal (Winataputra, 2008).

Indonesia memiliki berbagai macam sistem pendidikan atau pembelajaran, salah satunya yaitu pendidikan pesantren yang dikategorikan sebagai subkultur dalam masyarakt Indonesia, karena memiliki ciri khas yang unik dan tidak diragukan lagi kualitasnya. Pesantren dipandang sebagai salah satu lembaga pendidikan yang menjadi pusat awal dimulainya perubahan-perubahan sosial (Haris, 2017). Selain itu, pesantren dikenal sebagai lembaga pendidikan yang memiliki ciri khas, seperti berprinsip keikhlasan, kesederhanaan, kebersamaan, kekeluargaan, kesopanan, beriman dan bertakwa, serta kemandirian. Pendidikan pesantren yang merupakan bagian dari sistem pendidikan nasional memiliki tiga unsur utama, yaitu: (a) kiai sebagai pemilik sekaligus pendidik bagi para santri; (b) kurikulum pesantren; dan (c) sarana peribadatan dan pendidikan seperti masjid, madrasah, pondok, dan lain-lain. Dalam pasal 3 Undang-Undang Sistem Pendidikan Nasional (UU Sisdiknas) menjelaskan bahwa pendidikan nasional berfungsi untuk mengembangkan kemampuan dan membentuk watak serta peradaban bangsa yang bermartabat dalam rangka mencerdaskan kehidupan bangsa, bertujuan untuk mengembangkan potensi peserta didik agar menjadi manusia yang beriman dan bertakwa kepada Tuhan Yang Maha Esa, berakhlak mulia, sehat, berilmu, cakap, kreatif, mandiri dan menjadi warga negara yang demokratis, serta bertanggung jawab. Ketentuan tersebut telah berlaku dan diimplementasikan di pesantren. Sejak lama, pesantren sudah menjadi lembaga yang membentuk peradaban serta mencerdaskan kehidupan bangsa yang berbasis keimanan dan ketakwaan kepada Allah Swt, yang dilengkapi dengan akhlak mulia (Arifin, 2016).

Salah satu aliran pembelajaran dalam ilmu psikologi yaitu aliran humanistik, yang mengatakan bahwa proses belajar harus dimulai dan ditunjukkan untuk kepentingan memanusiakan manusia itu sendiri. Teori ini lebih mementingan orang yang dipelajari dibandingkan dengan proses belajar itu sendiri (Khairani, 2017). Aliran humanistik dalam pendidikan mengusung prinsip 
memperdayakan setiap manusia sebagai individu yang bebas untuk mengembangkan potensinya, serta dapat mengaktualisasikan dirinya. Pengimplementatasian humanistik dalam pendidikan berkonstribusi dalam membentuk peserta didik yang memiliki karakter atau sifat-sifat positif, peduli terhadap sesama (hablum minannas), dan bisa mengembangkan potensi-potensi yang ada di dalam dirinya sendiri. Pengembangan potensi dapat menciptakan manusia unggul dan berhati nurani (humanis) (Hibana et al., 2015; Jumarudin et al,, 2014; Lynch \& Cicchetti, 1997; Sidhiq, 2016). Sedangkan Carl Rogers yang terkenal dengan teori belajar humanistik dan terapi yang berpusat pada klien (client centered therapy), mengatakan bahwa jika hal itu diterapkan, maka akan menghasilkan peserta didik (output) yang humanis, mandiri, kreatif, bertanggung jawab, pantang menyerah, berdaya saing, dan lain sebagainya (Parjuangan, 2016). Aliran humanistik ini dapat terlaksana dengan optimal dalam pendidikan jika kelas, kurikulum, sistem atau model pembelajaran dan pengajaran, serta pendidik telah menggunakan prinsip-prinsip dan konsep pendidikan humanistik (Dwiningrum, 2016; Putri, 2018).

Secara praktis, pengimplementasian aliran humanistik dalam sistem pendidikan dapat dikombinasikan dengan teknologi, kursus studi lapangan, dan model pembelajaran lainnya. Penelitian tersebut mengatakan bahwa penerapan pendekatan humanistik terhadap pembelajaran bisa meningkatkan dan mengembangkan potensi peserta didik, baik dari keilmuan maupun dari sikap kemanusiaannya (Alagona \& Simon, 2010; Faqihuddin, 2017; Tabatabaie, 2013). Hal itu berkaitan dengan perkembangan kognitif siswa, adapun tahapan perkembangan kognitif yang paling tinggi menurut Jean Piaget adalah tahap operasional formal, sebab dalam tahap tersebut anak-anak sudah mampu berpikir abstrak, mampu menangani masalah dalam semua bingkai waktu (masa lalu, sekarang, atau masa depan), selain itu ia juga mampu memahami bentuk argumen dan tidak dibingungkan oleh argumen itu sendiri (Salkind, 2009). Berdasarkan penjelasan di atas penulis ingin menggabungkan serta menganalisis teori konsep belajar humanistik dari Carl Rogers dan tahapan perkembangan kognitif dari Jean Piaget terhadap siswa yang ada di pesantren. Oleh sebab itu, tujuan dari penelitian ini adalah untuk mengetahui serta menganalisis pengimplementasian konsep belajar humanistik pada siswa tahap operasional formal yang ada di Sekolah Menengah Kejuruan (SMK) Miftahul Khair.

\section{Metode}

Penelitian ini merupakan penelitian kualitatif yang mengacu pada pendapat Creswell, yakni bahwa informasi tentang proses pembelajaran humanistik dideskripsikan berdasarkan perspektif dari objek atau partisipan yang dalam konteks ini guru dan siswa (Creswell, 2012) yang bersifat 
pandangan subjektif. Lokasi penelitian di yayasan pondok pesantren Raudhatul Mubtadiin yang terletak di salah satu desa di Pamekasan, Madura.

Subjek penelitian ini dipilih dengan purposive sampling berjumlah tiga guru SMK Miftahul Khair dengan kriteria telah mengajar lebih dari satu tahun. Pengambilan data dilakukan dengan wawancara semi-terstruktur dengan kisi-kisi pedoman pertanyaan, yaitu: (1) Terkait dengan strategi guru dalam menumbuhkan serta meningkatkan hasrat belajar siswa; (2) Mengenai metode yang digunakan guru untuk membuat belajar yang bermakna bagi siswa; (3) Mencari tahu apakah guru melakukan proses pembelajaran tanpa ancaman; (4) Terkait dengan bagaimana cara guru untuk membuat siswa belajar dengan inisiatif sendiri; dan (5) mengenai perubahan siswa dalam proses pembelajaran yang digunakan oleh guru. Wawancara difokuskan untuk mengetahui strategi yang digunakan guru dalam mengimplementasikan pembelajaran humanistik terhadap siswa. Selain wawancara, observasi juga dilakukan sebagai teknik pengambilan data dalam penelitian ini untuk menguatkan serta melengkapi hasil yang diperoleh dari wawancara. Hal itu dilakukan dengan mengamati proses pembelajaran antara guru dan siswa saat berada di dalam kelas, dengan cara peneliti ikut serta dalam pembelajaran sebagai guru bantu. Peneliti juga mengamati interaksi antara guru dan siswa saat berada di luar kelas, karena hal ini menjadi faktor pendukung dalam penelitian ini. Adapun subjek yang diambil dalam penelitian ini adalah guru yang mengampu mata pelajaran produktif, mulok fikih, dan guru piket.

\section{Tabel 1}

\section{Partisipan Penelitian}

\begin{tabular}{cccc}
\hline Inisial & Jenis kelamin & Mata pelajaran & Lama mengajar \\
\hline IN & Perempuan & Produktif & 6 tahun \\
NA & Perempuan & Guru piket & 1,6 tahun \\
MR & Laki-Laki & Mulok fikih & 11 tahun \\
\hline
\end{tabular}

Catatan. Lama mengajar terhitung sejak pertama kali menjadi guru di SMK Miftahul Khair hingga tahun 2020.

Analisis dan interpretasi data dalam penelitian ini berkaitan dengan segmentasi dan pemilahan data yang dibutuhkan serta menyusunnya kembali. Analisis data dalam penelitian ini berlangsung bersamaan dengan bagian-bagian lain dari perkembangan penelitian kualitatif, yaitu pengumpulan data dan penulisan temuan (Creswell, 2014). Ada tiga langkah besar dalam melakukan analisis data kualitatif, yang pertama adalah kode terbuka (open coding), di mana peneliti berupaya menemukan selengkap dan sebanyak mungkin variasi data yang ada di lokasi penelitian, hal ini dilakukan peneliti dengan cara melakukan triangulasi teknik (wawancara dan observasi). Alasan menggunakan triangulasi, karena tidak 
adanya metode tunggal yang cocok dan sempurna dalam penelitian ini. Triangulasi juga berguna sebagai penguji validasi dan reliabilitas data, selain itu variasi data juga berguna untuk saling menguatkan data yang menjadi titik fokus dari penelitian ini. Kedua, kode aksial (axial coding), di mana hasil yang diperoleh kemudian ditemakan berdasarkan kategori-kategori untuk dikembangkan ke arah proposisi, yaitu dengan cara memakai teori humanistik dari Carl Rogers sebagai tema utama, dan prinsip-prinsip belajar humanistik sebagai kategorinya. Pada tahap ini peneliti melakukan analisis hubungan antar kategori, agar mendapatkan gambaran umum tentang hasil penelitian ini. Ketiga, pengodean selektif (selective coding), di mana setelah data dianalisis kemudian peneliti menggolongkan kategori tersebut menjadi kriteria inti dan pendukung serta mengaitkannya. Selanjutnya, peneliti memberikan hubungan antar-kategori yang akhirnya menghasilkan simpulan dalam penelitian ini (Hibana et al., 2015).

\section{Hasil}

\section{Latar belakang objek penelitian}

Sekolah Menengah Kejuruan Miftahul Khair adalah salah satu lembaga di bawah naungan Pondok Pesantren Raudhatul Mubtadiin yang terletak di desa Cenlecen, kecamatan Pakong, kabupaten Pamekasan. Jurusan yang ada di sekolah ini adalah Rekayasa Perangkat Lunak (RPL), dengan mengusung visi misi yang sangat kental dengan agama dan keagaamaan. Hal ini disebabkan oleh pesantren yang menaungiya, yang juga berimbas pada kurikulum dan sistem pembelajaran yang digunakan dalam lembaga tersebut. Guru-guru yang mengajar di lembaga ini merupakan orang yang sudah kompeten di bidangnya masingmasing dan berperan sebagai fasilitator bagi siswa. Maka, dengan peran tersebut guru harus menempatkan dirinya sebagai sumber yang dapat dimanfaatkan oleh peserta didik. Menurut Sukmadinata dan Syaodih (Sukmadinata \& Syaodih, 2007), beberapa ciri guru sebagai fasilitator di antaranya adalah: (a) merespon perasaan peserta didik, (b) menggunakan ide atau gagasan peserta didik untuk melakukan interaksi yang sudah dirancang, (c) berdialog dan berdiskusi dengan peserta didik, (d) menghargai peserta didik, (e) kesesuaian antara ucapan dan perilaku guru, serta (f) menyesuaikan diri dengan kerangka berfikir peserta didik. Hal tersebut di atas sudah diaplikasikan oleh subjek dalam proses pembelajaran, baik di dalam maupun di luar kelas, lebih lanjut hal itu akan dijelaskan dalam hasil penelitian.

\section{Hasil wawancara}

\section{Pemberian respon positif kepada siswa}

Dari hasil wawancara yang didapat dari ketiga subjek diketahui bahwa ketiganya melakukan proses pembelajaran dengan memberikan sikap positif terhadap siswa agar bisa membuatnya merasa nyaman, sehingga siswa tidak merasa tertekan dan bisa maksimal 
dalam proses pembelajaran. Hal itu dilakukan dengan memberikan respon positif sebagai penguat terhadap siswa baik secara verbal maupun nonverbal seperti: tersenyum dan memberikan pujian, mencoba memahami siswa dan tidak membeda-bedakan karakter, serta kemampuan setiap siswa. Hal tersebut diterapkan oleh subjek 1 (IN) serta subjek 3 (MR). Selain itu subjek 1 (IN) dan subjek 2 (NA) juga memberikan kebebasan kepada siswa untuk mengevaluasi metode belajar yang ia gunakan agar bisa mengetahui kekurangan, kelebihan, serta keinginan siswa dalam proses pembelajaran. Selain itu, subjek 2 (NA) menambahkan bahwa, ia menganggap siswa seperti anak sendiri, agar ia bisa memiliki rasa tulus dan ikatan emosional dalam proses pembelajaran. Hal tersebut dilakukan karena ia percaya bahwa hati (perasaan) mempunyai koneksi dengan hati lainnya. Sedangkan hasil wawancara terhadap subjek 3 (MR), beliau mengatakan bahwa:

\begin{abstract}
"Saya sebisa mungkin selalu memberikan reward atau apresisasi kepada siswa yang berprestasi, yah meskipun itu hanya sebatas pujian, dan tepuk tangan. Tapi saya yakin kalau itu bisa membuat siswa merasa bahagia dan dihargai atas kerja kerasnya, sehingga siswa berusaha mempertahankan prestasinya." (Wawancara subjek 3 = MR)
\end{abstract}

Cara tersebut dilakukan oleh ketiga subjek karena bisa membuat siswa merasa nyaman, merasa dihargai, tidak tertekan, mendapat kebebasan, dan tidak didiskriminasi. Dampak dari perilaku subjek sebagaimana yang telah dijelaskan di atas, membuat hasrat belajar siswa meningkat.

\section{Cerita inspiratif membawa perubahan terhadap siswa}

Dari hasil wawancara diketahui bahwa ketiga subjek sering memberikan cerita inspiratif baik dari tokoh terkenal, seperti Nabi Muhammad Saw, B.J. Habibie, dan lain-lain, hingga cerita pribadi yang bisa menginspirasi siswa. Hal tersebut dilakukan untuk menumbuhkan motivasi intrinsik siswa agar melakukan perubahan dengan menikmati prosesnya. Adapun motivasi intrinsik memiliki posisi penting dalam aliran ini. Menurut salah satu subjek penelitian, yakni subjek 3 (MR), hal tersebut terjadi karena cerita inspiratif membuat siswa memiliki pandangan ke depan tentang dirinya. Melalui hal tersebut, siswa terdorong untuk merealisasikannya dengan cara melakukan perubahan atau memperbaiki kualitas diri. Perbedaan strategi ketiga subjek dalam hal ini adalah berkaitan dengan sudut pandang serta tokoh yang dijadikan inspirasi terhadap siswa. Subjek 1 (IN) lebih cenderung menceritakan tokoh-tokoh kekinian yang sukses meraih cita-citanya dan menjadi orang sukses dengan cara dan sifat yang ia miliki, seperti B.J. Habibie, Mahfud MD, dan lain sebagainya. Adapun subjek 2 (NA) hampir sama dengan subjek 1 (IN), akan tetapi subjek 2 (NA) lebih sering mengutip cerita dari tokoh-tokoh yang ada di lingkungan lembaga tersebut untuk mengisnpirasi siswa. Dalam hal ini, biasanya NA mengambil sifat atau sikap positif tokoh 
tersebut untuk dijadikan inpirasi bagi siswa, seperti guru yang ulet, gigih, dan disiplin. Sedangkan subjek 3 (MR) lebih cenderung bercerita tentang nabi dan para sahabatnya, hal itu karena ia mengajar tentang hal yang berkaitan dengan agama. Dalam hal ini, ia menceritakan tokoh dari sisi sifat atau perilaku yang ia miliki, seperti Sayyidina Abu Bakar dengan sifat jujurnya, Sayyidina Umar dengan keberaniannya, Bilal dengan kegigihannya, dan lain sebagainya.

\section{Metode pembelajaran yang menyenangkan}

Sebelum memulai pelajaran, terkadang subjek melakukan kuis untuk merangsang ingatan siswa tentang pelajaran yang telah berlalu. Hal ini sangat efektif untuk membudayakan sikap kompetitif dalam belajar bagi siswa. Selain itu, ketiga partisipan khususnya subjek 1 (IN) sering melakukan praktik untuk mendukung proses pembelajaran agar siswa mudah memahami dan mengingat hal yang sedang dipelajari (belajar bermakna). Subjek 2 (NA) mengatakan bahwa, dengan menjadikan kuis dan praktik sebagai salah satu metode pembelajaran yang berbasis humanistik bagi siswa, selain mendapat keuntungan di atas, hal tersebut juga menjadikan belajar lebih menyenangkan dan tidak membosankan bagi siswa. Akan tetapi menurut subjek 1 (IN), tidak semua materi dilakukan dengan cara praktik, seperti ungkapannya:

"Iya, saya tidak selalu memberikan praktik dalam proses pembelajaran, karena kadang ada pelajaran yang hanya menjelaskan teori saja. Yaah intinya saya melakukan praktik jika itu memang dibutuhkan". (Wawancara subjek $1=$ IN)

Selain penggunaan metode di atas, ketiga subjek juga mengaplikasikan beberapa model pembelajaran lain, yaitu: (1) Metode pembelajaran yang berpusat pada siswa (student centered learning/SCL) seperti diskusi; dan (2) Pembelajaran yang dipercepat (the accelerated learning) seperti penggunaan media pendukung dan praktik langsung, agar pembelajaran lebih variatif dan tidak membosankan.

\section{Penguatan negatif sebagai cara terakhir}

Selain memberikan beberapa upaya di atas, ketiga subjek dalam mengimplentasikan pembelajaran humanistik terkadang juga mengombinasikannya dengan aliran pembelajaran lain seperti behaviorisme, dengan menggunakan penguatan negatif terhadap beberapa siswa yang bisa dibilang "tidak mudah ditangani". Menurut hasil wawancara, sebelum subjek memberikan penguatan negatif pada siswa yang sulit diatur, ia memberikan arahan terlebih dahulu dengan bekerja sama dengan guru Bimbingan Konseling (BK) yang ada. Akan tetapi, jika hal itu tidak berhasil, maka biasanya subjek akan memberikan penguatan negatif terhadap siswa, seperti meminta siswa maju ke depan, berdiri di tempat, dan menjawab pertanyan guru. Hal ini hampir dilakukan oleh ketiga subjek terhadap kasus-kasus tertentu yang dianggap "keluar batas". 


\section{Pembahasan}

\section{Konsep belajar humanistik}

Secara garis besar, teori humanistik ini lebih menekankan pada proses pembelajaran, bukan pada hasil belajar. Teori ini memiliki konsep memanusiakan manusia (peserta didik), sehingga ia mampu mengenali dirinya serta lingkungan sekitarnya. Terdapat beberapa tokoh yang menonjol dalam aliran ini, yaitu Combs, Maslow, dan Rogers. Pengertian humanistik yang beragam membuat batasanbatasan aplikasi teori humanistik dalam dunia pedidikan juga menjadi beragam (Sumanto, 2014). Oleh karena itu, peneliti hanya menggunakan satu tokoh dalam penelitian ini, yaitu Carl Rogers. Ia mengatakan bahwa belajar adalah fungsi keseluruhan pribadi, lebih jelas ia mengatakan belajar yang sebenarnya tidak dapat berlangsung jika tidak ada keterlibatan intelektual maupun emosional peserta didik. Oleh karena itu, motivasi yang bersumber dari diri sendiri (siswa) sangat penting dalam aliran ini. Rogers juga membedakan dua ciri belajar, yaitu: (1) Belajar bermakna, terjadi apabila proses pembelajaran melibatkan aspek pikiran dan perasaan peserta didik; dan (2) Belajar tidak bermakna, terjadi jika proses pembelajaran melibatkan aspek pikiran, akan tetapi mengabaikan aspek perasaan peserta didik (Khairani, 2017).

Adapun prinsip belajar humanistik menurut Carl Rogers harus mencakup beberapa hal, yaitu hasrat untuk belajar, belajar yang berarti, belajar tanpa ancaman, belajar harus inisiatif sendiri, serta belajar dan perubahan (Irham \& Wiyani, 2016). Sedangkan hasil penelitian yang didapat dari tiga partisipan telah memenuhi syarat, dengan menggunakan prinsip-prinsip belajar yang dimiliki Carl Rogers yang digunakan sebagai acuan wawancara sebagai berikut.

\section{Hasrat untuk belajar}

Menurut pandangan Rogers, setiap individu mempunyai hasrat alami untuk belajar. Konsep dorongan ingin tahu tersebut merupakan asumsi dasar pendidikan dan pembelajaran dari sudut pandang humanistik. Dengan demikian proses pembelajaran yang menggunakan teori ini dapat diwujudkan dengan memberi kesempatan siswa untuk memberikan kebebasan terhadap rasa ingin tahunya, memenuhi minatnya, serta membantu siswa untuk menemukan hal yang berarti atau penting bagi dirinya sekarang atau di masa mendatang (Irham \& Wiyani, 2016).

Hal ini sesuai dengan temuan di lapangan bahwa guru di SMK Miftahul Khair dalam meningkatkan hasrat belajar serta menumbuhkan motivasi siswa, mengimplementasikannya dengan cara membuat siswa merasa nyaman terhadapnya, berusaha membuat kelas kondusif namun tetap menyenangkan dengan menggunakan metode pembelajaran yang berbasis humanistik, seperti memberikan kuis, diskusi, dan lain sebagainya. Selain itu, subjek juga memberikan cerita 
inspiratif terhadap siswa; melibatkan emosi siswa dengan berinteraksi dan memberikan respon positif, baik secara verbal maupun nonverbal, seperti acungan jempol, senyum, apresiasi dengan pujian dan tepuk tangan dan sebagainya; serta memberikan kebebasan terhadap siswa untuk mengeksplorasi rasa ingin tahunya terhadap suatu mata pelajaran. Sedangkan untuk memfasilitasi rasa keingintahuan siswa, guru selalu memberikan kesempatan bertanya bagi siswa, baik di dalam maupun di luar kelas, guna memenuhi hasrat alami siswa untuk belajar dan mengetahui sesuatu.

\section{Belajar bermakna}

Prinsip belajar yang berarti menjelaskan bahwa siswa hanya akan belajar dengan cepat dan berhasil, apabila materi yang dipelajari mempunyai arti baginya. Hal ini akan sangat mungkin terjadi apabila materi pelajaran yang dipelajari siswa sesuai dengan kebutuhan dan maksud siswa (Irham \& Wiyani, 2016). Dari hasil penelitian yang dilakukan, ditemukan bahwa untuk menjadikan belajar bermakna bagi siswa, subjek menyesuaikan materi dengan kebutuhan siswa. Menurut salah satu guru yang telah diwawancarai, diketahui bahwa sarana dan prasarana sangat penting utuk menjadikan proses belajar siswa lebih menyenangkan dan berarti (bermakna). Salah satu fasilitas yang ada di sekolah tersebut adalah laboratorium komputer. Hal tersebut menjadi penting karna spesialisasi sekolah ini adalah Rekayasa
Perangkat Lunak (RPL). Sehingga praktik dan alat peraga (metode belajar pembelajaran aktif) dalam pembelajaran selalu digunakan oleh subjek. Harapannya, dengan melakukan hal tersebut, siswa lebih mudah dalam memahami pelajaran, serta dapat membuat pengalaman belajar siswa tidak terlupakan (bermakna). Selain itu, terkadang guru menggunakan metode pembelajaran yang berpusat pada siswa (student centered learning), dengan harapan dapat membuat siswa aktif dalam membangun pengetahuan, sikap, serta perilaku. Hal ini biasanya dilakukan dengan cara diskusi atau melakukan kuis untuk mempertajam pemahaman siswa yang merupakan pembelajaran kuantum (quantum learning) yang dilakukan sebelum atau sesudah mata pelajaran.

\section{Belajar tanpa ancaman}

Proses belajar akan lebih mudah dilakukan oleh siswa apabila pelaksanaan proses belajar mengajar berlangsung dalam lingkungan yang terbebas dari ancaman yang dapat mengganggu atau bahkan membahayakan siswa (Irham \& Wiyani, 2016). Dari temuan yang didapat oleh peneliti, lingkungan yang ada di lembaga tersebut telah dikondisikan sedemikian rupa agar siswa merasa nyaman, kondusif, dan fokus dalam melakukan proses belajar. Menurut hasil wawancara, diketahui bahwa guru memberikan dorongan terhadap siswa untuk pantang menyerah, yaitu dengan mencoba lagi 
dan lagi sampai siswa berhasil, tanpa memberikan ancaman atau kecaman (komentar negatif) yang dapat menyinggung perasaan siswa. Akan tetapi, dalam beberapa kasus biasanya guru akan memberikan peringatan atau bahkan hukuman ringan, seperti: maju ke depan kelas, berdiri, dan menjawab pertanyaan kepada siswa yang sudah melampaui batas. Hal itu diberikan untuk mengajak siswa menyadari kesalahannya dan memberikan efek jera pada siswa. Berdasarkan hasil wawancara yang didapat, salah satu contoh dari dorongan positif terhadap siswa tanpa memberikan ancaman, misalnya ketika pengerjaan tugas, guru tetap memberikan respon positif, baik kepada siswa yang mengerjakan tugas dengan baik maupun tidak seperti:

"Wah bagus sekali",

"Kerjamu sudah baik, namun masih ada yg perlu ditingkatkan atau diperbaiki."

(Wawancara subjek $1=\mathrm{IN}$ ).

\section{Belajar harus inisiatif sendiri}

Prinsip belajar atas insiatif sendiri menjelaskan bahwa belajar akan menjadi lebih berarti dan bermakna bagi siswa apabila proses tersebut dilakukan atas insiatif sendiri serta melibatkan perasaan dan pikiran siswa. Dengan demikian, proses belajar akan lebih efektif, serta membuat siswa lebih antusias dan bersemangat dalam proses belajarnya (Irham \& Wiyani, 2016). Dari penelitian yang didapat ditemukan bahwa untuk merekonstruksi pemikiran siswa bahwa belajar adalah kebutuhan pribadi, guru memberikan arahan bahwa belajar adalah kebutuhan untuk mejalani kehidupan serta sangat penting bagi individu, baik di masa sekarang maupun masa depan. Salah satu cara yang ia gunakan adalah dengan memberikan cerita inspiratif dari tokoh-tokoh ternama, baik dari masa lampau hingga masa kini, seperti Nabi Muhammad, B.J. Habibie, dan sebagainya, dengan tujuan agar memotivasi siswa dan menjadikan tokoh tersebut sebagai pedoman, idola, atau acuan untuk ditiru oleh siswa. Hasilnya, siswa lebih bersemangat dan atusias dalam proses pembelajaran karena mereka menyadari bahwa belajar itu penting guna mencapai cita-cita yang mereka inginkan.

\section{Belajar dan perubahan}

Rogers menjelaskan bahwa belajar yang paling bermanfaat bagi siswa adalah tentang proses belajar itu sendiri. Ilmu pengetahuan terus mengalami kemajuan dan perkembangan yang pesat hingga saat ini. Oleh sebab itu, yang dibutuhkan siswa adalah individu (pendidik) yang mampu belajar di lingkungan yang sedang dan akan terus berubah. Artinya belajar adalah untuk mempersiapkan siswa untuk hidup dan mampu menghadapi masa depan. Belajar akan terus memunculkan perubahan, baik dari siswa itu sendiri maupun dari apa yang dipelajarinya. Hal ini membuat siswa akan terus menerus belajar karena adanya perubahan dan perkembangan atas apa yang dipelajarinya (Irham \& Wiyani, 2016). 
Visi yang diusung oleh SMK Miftahul Khair, yaitu "menjadi lembaga pendidikan yang menghasilkan sumber daya manusia yang profesional dan mampu berkompetisi di tingkat lokal, nasional, maupun internasional". Visi tersebut membuat lembaga ini berusaha mempersiapkan kurikulum, tenaga pengajar, serta sarana dan prasana yang memadai, agar mampu mencapai apa yang telah diharapkan. Menurut hasil wawancara, diketahui bahwa proses belajar mengajar berbasis humanistik yang dilakukan telah memberikan perubahan bagi siswa, baik dari pengetahuan maupun perilaku siswa, seperti siswa lebih memiliki wawasan luas terhadap suatu disiplin ilmu, memiliki pandangan kedepan, lebih mandiri, kritis terhadap sesuatu, dan bertanggung jawab. Selain itu, guru terus melakukan inovasi terhadap metode yang ia gunakan dengan meminta pendapat siswa. Biasanya guru meminta siswa untuk menulis pendapatnya baik berupa kekurangan maupun kelebihan metode yang digunakan guru selama proses belajar mengajar secara anonim agar siswa lebih terbuka dan jujur dalam menyampaikan pendapatnya.

\section{Tahap operasional formal}

Tahap operasional formal adalah salah satu tahapan dalam perkembangan kognitif menurut Piaget. Sebelum membahas tentang tahapan tersebut, definisi tentang kognitif perlu diketahui terlebih dahulu. Adapun istilah kognitif menurut Chaplin adalah salah satu wilayah atau domain atau ranah psikologis manusia yang meliputi perilaku mental yang berhubungan dengan pemahaman, pertimbangan, pengolahan informasi, pemecahan masalah, kesengajaan, dan keyakinan. Ranah kognitif juga memiliki hubungan dengan konasi (kehendak) dan afeksi (perasaan) (Syah, 2013). Oleh sebab itu, proses belajar selalu berkaitan dengan proses kognitif seseorang. Adapun tahap perkembangan kognitif menurut Piaget adalah: (1) Tahap sensori motor yang terjadi pada usia 0 - 2 tahun, ditandai dengan pemikiran yang berdasarkan tindakan indrawinya; (2) Tahap praoperasional formal yang terjadi pada usia 2 - 7 tahun, ditandai dengan penggunaan simbol untuk menghadirkan benda atau pemikiran, khususnya penggunaan bahasa; (3) Tahap operasional konkret yang terjadi pada usia 8 11 tahun, ditandai dengan penggunaan aturan logis yang jelas; dan (4) Tahap operasional formal yang terjadi pada usia 11 tahun ke atas, ditandai dengan mampu berpikir abstrak, logis dan probabilitas, berpikir deduktif-induktif, serta mampu membuat hipotesis dan kesimpulan (Suparno, 2001).

Menurut Ginsburg dan Opper, seseorang pada tahap operasional formal mempunyai tingkat ekuilibrium yang tinggi, dapat berpikir fleksibel dan efektif, mampu berhadapan dengan persoalan yang kompleks, serta ia dapat berpikir fleksibel karena dapat melihat semua unsur dan kemungkinan yang ada (Suparno, 2001). Alasan mengapa ia bisa berpikir efektif adalah karena ia dapat mengidentifikasi 
pemikiran mana yang cocok untuk persoalan yang dihadapi. Selain itu, ia juga mampu menganalisis, memikirkan solusi, atau kemungkinan-kemungkinan lain dari masalah yang ia hadapi. Dari penjelasan di atas, disimpulkan bahwa tahap operasional adalah tahapan tertinggi dalam perkembangan kognitif manusia, hal itu membuat seseorang dalam tahap ini memiliki pemikiran yang kompleks. Berdasarkan hasil penelitian ini, telah dijelaskan bahwa ciri-ciri siswa tahap operasional formal yang ada, sama persis dengan apa yang disebutkan dalam teori Piaget. Jadi, selain terletak pada usia siswa (16 - 18 tahun), siswa juga mampu berpikir kritis, logis (deduktifinduktif), mampu membuat hipotesis, dan bahkan memecahkan masalah yang ia hadapi. Hal ini bisa dilihat saat proses pembelajaran siswa, baik yang bersifat praktik maupun tidak, misalnya seperti penugasan. Akan tetapi, ada pula siswa yang kurang aktif atau antusias dalam pembelajaran, sehingga mereka kurang kritis terhadap permasalahan yang ada. Hal itu menjadi tugas guru untuk menumbuhkan semangat dan memotivasi siswa agar mampu belajar kooperatif dan efektif.

\section{Simpulan}

Berdasarkan hasil penelitian yang telah dipaparkan di atas, dapat disimpulkan bahwa strategi, metode, serta perilaku guru sangat penting dalam pengimplementasian konsep belajar humanistik bagi siswa. Penggunaan metode humanistik dalam proses belajar mengajar di SMK Miftahul Khair memberikan dampak positif dan negatif bagi siswa. Adapun dampak positif di antaranya siswa mampu belajar atas inisiatif sendiri, merasa nyaman saat belajar, merasa dihargai, tidak membedakan atau mendiskriminasi siswa, serta siswa bebas dalam mengeskplorasi rasa keingintahuannya tanpa ada ancaman. Sedangkan dampak negatifnya, terdapat beberapa siswa yang mengabaikan proses pembelajaran sehingga ia kurang mampu memahami materi yang diberikan. Hal ini terjadi karena tidak adanya ancaman dari guru. Akan tetapi, pada kasus tertentu, guru memberikan hukuman (punishment) ringan terhadap siswa seperti maju ke depan kelas, berdiri, menjawab pertanyaan dari guru, dan sebagainya. Hal tersebut dilakukan agar siswa menyadari kesalahannya dengan harapan dapat memberikan efek jera terhadap siswa.

\section{Saran}

Saran yang dapat peneliti berikan bagi lembaga yang bersangkutan adalah agar lembaga dapat mengadakan seminar atau pelatihan yang dapat menumbuhkan gairah dan prestasi belajar siswa. Selain itu, guru juga dapat menanamkan nilai-nilai positif pada siswa dengan tidak hanya melalui ucapan saja, akan tetapi diikuti aksi nyata. Sehingga, guru dapat menjadi model positif yang bisa ditiru oleh siswa dalam lembaga tersebut. 


\section{Referensi}

Alagona, P. S., \& Simon, G. L. (2010). The role of field study in humanistic and interdisciplinary environmental education. Journal of Experiential Education, 32(3), 191-206. https:// doi.org/10.1177/105382590903200302

Arifin, M. (2016). Manajemen keuangan pondok pesantren. Fikrotuna, 4(2), 10-24. https:/ /doi.org/10.32806/jf.v4i2.2745

Creswell, J. W. (2012). Educational research: Planning, conducting, and evaluating quantitative and qualitative research (4th ed.). Pearson.

Creswell, J. W. (2014). Research design: Qualitative, quantitative, and mixed methods approaches (4th edition, international student edition). SAGE.

Dwiningrum, S. I. A. (2016). Menciptakan belajar humanis tantangan pendidik yang profesional dan berkarakter. Jurnal Pembangunan Pendidikan: Fondasi Dan Aplikasi, 4(2), 154-165. https://doi.org/ 10.21831/jppfa.v4i2.12420

Faqihuddin, A. (2017). Internalisasi nilai-nilai humanistik religius pada Generasi Z dengan "Design for Change." Edukasia: Jurnal Penelitian Pendidikan Islam, 12(2), 263-284. https://doi.org/ 10.21043/edukasia.v12i2.2471

Haris, A. (2017). Sistem pendidikan di Pondok Pesantren Mansyaul Ulum Congkop Nagasari Tlambah Kecamatan Karang Penang Kabupaten Sampang. Al-Ulum: Jurnal Penelitian Dan Pemikiran Keislaman, 4(1), 59-72. https://doi.org/ 10.31102/alulum.4.1.2017.59-72

Hibana, Kuntoro, S. A., \& Sutrisno. (2015). Pengembangan pendidikan humanis religius di madrasah. Jurnal Pembangunan Pendidikan: Fondasi Dan Aplikasi, 3(1), 19-30. https://doi.org/ 10.21831/jppfa.v3i1.5922

Irham, M., \& Wiyani, A. N. (2016). Psikologi pendidikan: Teori dan aplikasi dalam proses pembelajaran (Ketiga). Ar-Ruzz Media.
Jumarudin, Gafur, A., \& Suardiman, S. P. (2014). Pengembangan model pembelajaran humanis religius dalam pendidikan karakter di sekolah dasar. Jurnal Pembangunan Pendidikan: Fondasi Dan Aplikasi,2(2), 114-129. https://doi.org/ 10.21831/jppfa.v2i2.2623

Khairani, M. (2017). Psikologi Belajar. Aswaja Pressindo.

Lahir, S., Ma'ruf, M. H., \& Tho'in, M. (2017). Peningkatan prestasi belajar melalui model pembelajaran yang tepat pada sekolah dasar sampai perguruan tinggi. Jurnal Ilmiah Edunomika, 1(1), 1-8. https://doi.org/10.29040/jie.v1i01.194

Lynch, M., \& Cicchetti, D. (1997). Children's relationships with adults and peers: An examination of elementary and junior high school students. Journal of School Psychology, 35(1), 81-99. https:// doi.org/https://doi.org/10.1016/S00224405(96)00031-3

Nurhasanah, S., \& Sobandi, A. (2016). Minat belajar sebagai determinan hasil belajar siswa. Jurnal Pendidikan Manajemen Perkantoran, 1(1), 128. https://doi.org/ https://doi.org/10.17509/ jpm.v1i1.3264

Parjuangan. (2016). Kreativitas dalam perspektif teori humanistik Rogers dan relevansinya dalam pendidikan. At-Tajdid: Jurnal Ilmu Tarbiyah, 5(2), 279-299.

Putri, E. I. E. (2018). Humanis dalam mendidik (Analisis terapan aliran psikologi humanistik). Jurnal Tarbiyatuna/ : Kajian Pendidikan Islam, 2(2), 50-65.

Salkind, N. J. (2009). Teori-Teori Perkembangan Manusia (Pertama). Penerbit Nusa Media.

Sidhiq, N. (2016). Humanisme pendidikan pesantren.Jurnal Al-Qalam, 11(1), 21-34.

Sukmadinata, \& Syaodih, N. (2007). Landasan psikologi proses pendidikan (IV). Remaja Rosdakarya.

Sumanto. (2014). Psikologi umum. Center Academic Publishing Service. 
Suparno, P. (2001). Teori Perkembangan KognitifJean Piaget. Kanisius.

Syah, M. (2013). Psikologi Pendidikan Dengan Pendekatan Baru (18th ed.). PT Remaja Rosdakarya.

Tabatabaie, A. K. M. (2013). Humanistic education: Concerns, implications and applications. Journal of Language Teaching and Research,
4(1), 45-51. https://doi.org/ 10.4304/jltr.4.1.45-51

Winataputra, D. U. S. (2008). Teori belajar dan pembelajaran. Universitas Terbuka.

Received 31 January 2020

Revised 20 April 2020

Accepted 30 May 2020 